\title{
Legal Strategies to Resolve Problems of Marital Relationships in the Quran
}

\author{
Seyed Mohammad Asadinejad ${ }^{1}$ \\ ${ }^{1}$ Department of Law, University of Guilan, Rasht, Iran \\ Correspondence: Seyed Mohammad Asadinejad, Departeman of Law, University of Guilan, Rasht, Iran, PO box \\ 3756. Tel: 98-911-137-4995. E-mail: asadinezhad@guilan.ac.ir
}

Received: February 22, 2012 Accepted: March 5, 2012 Online Published: August 21, 2012

doi:10.5539/jpl.v5n3p81 URL: http://dx.doi.org/10.5539/jpl.v5n3p81

\begin{abstract}
Sometimes either of the spouses might have abomination or marital misconduct towards the other. This deed which leads to problems in marital relationships is called nushuz, or lack of submission, and can be from either the husband or the wife. Nushuz is the mostly observed factor in divorce so its prevention can save the family break-up. The purpose of this article is to describe the possible mechanism available in this area. The holy Quran also offers some solutions to remove the problems of marital misconducts which cause damage to the family foundation by making the husband primarily responsible for reforming the family prima, and has presented conventional practices. To avoid any kind of damage to the family foundation the husband should practice admonishment and banishment. However, it should not cause bruises on her body or lead to a more strained relationship. Moreover, if the wife is nashiza (rebellious), selecting arbiters from among relatives of the spouses can solve any problem which had led to nushuz and lack of submission. We will discuss the process of reforming the family after an instance of nushuz, which is essential in bringing the relationship back to normal.
\end{abstract}

Keywords: nushuz (rebellion), marital misconduct, admonishment, banishment, beating, arbitration

\section{Introduction}

Family is the natural and fundamental element of society. Its vitality and liveliness causes the society to be vital and lively, and insecurity in it causes insecurity in the society. In order for the family foundation to be strong and for disputes to settle, special rules and regulations are needed that much of it is based on love and mercy. Most of the problems, including mental, emotional, and sexual disruptions and despondencies are settled using special strategies which are based on love and mercy. Rigidity of the marital relationship and problems in the relationship between the spouses (whatever the cause is) may finally result in lack of submission and break-down of the family. On the other hand misconduct and misbehavior can also cause problems in all aspects of family life and weaken the foundation of the family. In this article we analyze nushuz and discuss legal and Quranic solutions for it.

\subsection{The Concept of Nushuz}

An-nashz means a high place (Qharshi, 1991,). This word is also used in al-Mujadilah (the pleader), verse 11:

$O$ believers, when it is said to you 'Make room in the assemblies', then make room, and God will make room for you; and when it is said, 'Move up', move up, and God will raise up in rank those of you who believe and have been given knowledge. And God is aware of the things you do (the pleader, verse 11).

Absolute an-nashz is leaving a high place, and we'll see that doing so results in losing one's status, while "making room" (as mentioned in the verse) for servants of God, results in resolution of problems by God the almighty (Mostafavi, 1981).

Nushuz is when either of the spouses has abomination and marital misconduct towards the other (Ibn Manzur, 1987). The jurisprudential definition is not far from the lexical definition. Saheb Javaher defines it as refusal of fulfilling one's duties from either of the spouses (Najafi, Bita, vol. 31, p 207). Sheikh Tusi by giving examples defines it as profanation (Sheikh Tusi, vol. 4, p 337). Actually nushuz is the gradual disobedience and relinquishment of the spouse's essential rights (Balaghi Najafi, 1999). Nushuz is in contrast to submission, which means acceptance (Amid, 1993). 
All in all nushuz is a psychological condition and has various instances, such as misconduct, and not maintaining for wife and children. This deed which leads to problems in sexual relations of the spouses and abomination is not specific to one of the spouses (Najafi \& Ghartabi, 1995). The word nushuz with the abovementioned concept appears in two verses from the holy Quran. First in verse 34 of surah an-Nisa (women):

Men are the managers of the affairs of women for that God has preferred in bounty one of them over another, and for that they have expended of their property. Righteous women are therefore obedient, guarding the secret for God's guarding. And those you fear may be rebellious admonish; banish them to their couches, and beat them. If they then obey you, look not for any way against them; God is All-high, All-great.

The second instance is in verse 128 of surah an-Nisa:

If a woman fear rebelliousness or aversion in her husband, there is no fault in them if the couple set things right between them; right settlement is better; and souls are very prone to avarice. If you do good and are godfearing, surely God is aware of the things you do.

The first verse is about wife's nushuz and the second one about husband's nushuz.

\subsection{Managing the Family}

Family as a legal organization, like any other organization, needs to have a manager. The society has experienced different kinds of family managements. Once the wife was the head of the family and it experienced matriarchy. It has also experienced patriarchy to the fullest. Nowadays in many countries both spouses are the heads of the family. However, the holy Quran gives the leadership of this small community to men.

God has created human-beings and knows their complexities compared to others. So his ordinances and regulations are sage and wise, and are better than human regulations. Obviously as men are physically and emotionally different from women, they have more duties and responsibilities compared to women. Every community, small or large, needs a leader and family is not an exception. Moreover, family leadership is not just a right, but a kind of management which should not be misused. The maintenance of the family and spouse is of course on the shoulder of the head of the family. It seems that the man's leadership is not an imperative order and the parties can reach an agreement on it or manage the family together. However, in disputes man's leadership is inevitable. The superiority of men over women is just in management of affairs and bringing order to life and community. The real superiority of human-beings is based on their fear of God and virtuousness (Surely the noblest among you in the sight of God is the most gods fearing of you).

\section{Wife's Nushuz}

nushuz or lack of submission might be practiced by the wife. According to the definitions, abomination and misconduct together with hatred and reluctance, which is repeated and hinders the woman from obeying her husband, is called nushuz. It is obvious that having a sexual relationship with the husband is of the most basic duties of wives. The woman should obey her husband within the scope of law and custom, accept his leadership, and practice submission, in its general terms. However, if the husband has illicit or unconventional expectations, the woman is not obliged to obey him (Safaei, 2008). Therefore, insisting on limiting the concept of nushuz to lack of submission of wife in enjoyment is not essential. Many of the recent jurists also believe that lack of submission, in its general terms, is enough for realization of nushuz (Motahari, 1984).

If wife's nushuz is ascertained, verse 128 of surah an-Nisa has not given permission for unconventional treatment or even going to the court, but it suggests the following stages to him.

\subsection{Admonishment (va'z)}

It means giving advice and expressing Hadiths and religious edicts (Moien, 2005). If there's a problem in the sexual or marital relationship, the husband should follow this strategy before anything else. It is obvious that giving advice and council should be presented with a certain psychology and should not turn into reprimand, because this intensifies nushuz. Admonishment should be like guidance to the right and with useful hints and beneficial punishments (Mostafavi, 2005). Through admonishment the wife is reminded of her rights and duties (Kashani, 1957). However, because the foundation of family life is love and mercy (verse 21 of surah al-Rum) the Quranic family which is managed by the man should be full of love and mercy, and the husband should solve the problems by giving advice and council on emotional aspect, before thinking of the logical aspect of it. That's why Quran emphasizes on tranquility when it talks of family.

\subsection{Banishment (hijr)}

It means staying away from someone physically, verbally, or at heart (Ragheb Esfahani, p 514). But here it implies that the husband leave his wife alone in bed to determine her love or hatred toward him. In such cases if 
there's love left in women, they can't tolerate; but if there's no love, they wait (Tabresi, 1993). Anyway if admonishment does not work in the first place, the husband can eliminate nushuz by staying away from his wife.

Presenting such a strategy indicates that nushuz is not limited to lack of sexual submission, otherwise banishment would be ineffective or even intensify nushuz. Furthermore, the renowned belief is that admonishment and banishment should be practiced when there are signs of nushuz. The next stage, beating, is when nushuz occurs (Najafi \& Tusi, 1999).

\subsection{Beating (zarb)}

If the first two strategies prove ineffective, it's time to go to the stage of beating. Usually, in most cases the problem is resolved in the first two stages. If there's a strong probability that the problem would be solved through beating, it can be practiced. Therefore, the order of admonishment, banishment and beating should be observed (Najafi, Bita, vol. 31, 207). However, with the least probability of the ineffectiveness of the strategies mentioned earlier, it is suggested that the spouses go to the court (Jafari, 1997) and there's no permission for beating; because the principle of admonishment, banishment, and beating is to save the family foundation, and is not allowed if it threatens the foundation. So if there's fear of nushuz (and those you fear may be rebellious), i.e. if there are signs of it (Kazemi, 1986) and it is possible to eliminate it using the aforementioned strategies, instead of going to the court the husband can practice admonishment, banishment, and beating by observing the order; because going to the court might have an evil consequence or at least disclose the secrets of the family. Yet some of the scholars have not accepted beating, and tried to justify it in different ways. For example some believe that beating is only allowed if the society of the time does not think of it as an improper treatment in family life (Ibn Ashour, Bita, 440). Some believe that because zarb has a variety of meanings such as rejecting, walking, preventing, staying at home, changing, and sleeping together (Ibn Manzur, 556), we should consider caressing as the intended meaning; for if it meant beating there should be an indication of it in traditions and Hadiths, while it is banned in many of them (Ghaeni, 1994); some have interpreted it in a totally different way, and thought of zarb to mean "leaving home by the husband, so that the wife stops nushuz" (Abu Soleiman 2002: 39). Some other scholars have compared beating with slavery and believe that as slavery gradually abolished (scheduled abolition), beating, which was practiced by Arabs, was at first confirmed but gradually put an end to (Ma'refat, 2003). As the denial or abolition of such an order is illogical, some scholars think it is used ironically and only the ruler has the authority to do it (Bojnurdi, 1998). However, because beating is a right for the husband and is neither obligatory nor recommended, the order is fixed in all times (Javadi Amoli, 2005).

It is essential to mention that the principle of beating for the sake of the action is prohibited (Najafi, 202). Moreover, beating as the final stage should not intensify hatred. For instance, it is mentioned in some Hadiths that toothbrush should be used as the beating stick, so that it's out of love and friendship (Sadugh, 1981, \& Mofid, 1993) not hatred. This emphasis on beating with a toothbrush stick may be for the wife to think that the husband is teasing her (Bohrani, Bita, 618). What is inferred from Hadiths is that beating is limited to touching and should not bruise her body or lead to compensation. In fact, it's a way of implying dissatisfaction of the woman's behavior, and does not mean the conventional beating; because in some traditions this deed has been criticized by Prophet Mohammad, as he stated in a Hadith "How can you embrace the woman with a hand you had hit her with?" (Horr Ameli, 1971, \& Koleini, 1988). Therefore, it's obvious that the concept of beating as stated in the verse is totally different from conventional type. Performing such an action is a very sensitive concept and the smallest bit of aggression and insult is not covered to God. That's why the verse ends in a warning to men that they shouldn't misuse their power, as God's power is above all others. In fact, contemplation in the verse shows that husband as the family guardian has the responsibility of reforming the relationship. Maybe that's the reason Quran has addressed men 18 times and ordered him to prepare the atmosphere for a peaceful life: consort with them honorably (verse 19 of surah an-Nisa). Ibn Abbas, concerning verse 34 of surah an-Nisa, believes that the purpose of this verse ... women have such honorable rights as obligations, but their men have a degree above them ... is that the man should forgive a part of his rights but observe his wife's rights.; because God has first said men and women have equal and similar rights, and then invites men to prove their virtue and excellence over women by forgetting about some of their rights (Tabari, 1992). It is obvious that if the husband feels at every stage that he's not able to resolve the problem, he'd better use the arbitration system. Going to arbitration and choosing arbiters becomes obligatory, when other ways are blocked (Shahid Sani, 1993). It is necessary to mention that one of the ways of confronting nushuz is failiure to maintain. This is also considered in article 1104 of the civil code. 


\section{Husband's Nushuz}

Men's nushuz means molestation and annoyance from his side. If the man swears the woman without reason or turns away from her totally, i.e. does not keep her company or talk with her, and does not even maintain the family, his nushuz is realized (Jorjani, 1984).

Strategy of ending man's nushuz: according to the characteristics of either of the spouses and their condition in the family the same strategies does not apply for the husband; because psychology of women and men are different. When the flame of love dies in a man, the marriage also dies naturally (Motahari, 1974). It's the man who causes the woman to be cold and disinterested with his disinterest and disloyalty. Contrastingly, if disinterest starts from the woman it has no impact on the man's love (Safaei, 2004). Anyway, if the woman is not rebellious and observes all of the man's rights, but the man is incompatible removing nushuz is not as easy. Banishment and even admonishment might intensify nushuz. Therefore, the best strategy is to compromise. Compromise might be with or without consideration. It is obvious that if compromise did not benefit, then according to verse 35 of surah an-Nisa going to arbiter is the best solution. Although the woman is not rebellious, acting in accordance with the surface of the verse and going to an arbiter can simply lead to a compromise.

\section{Both Spouses' Nushuz}

Nushuz might be practiced by both sides. In this case, because it may end in divorce, it's called schism or breach (Majlesi, 1994). In verse 35 of surah an-Nisa the strategy of going to arbiters from among the relatives is suggested: And if you fear a breach between the two, bring forth an arbiter from his people and from her people an arbiter, if they desire to set things right; God will compose their differences; surely God is All-knowing, All-aware.

Based on the explicitness and the text of this verse if nushuz is from both sides, the strategy of going to an arbiter can prevent the family from breaking down. Similarly if nushuz is from one of the spouses and the strategies mentioned in verses 34 and 128 of surah an-Nisa are not effective, because of the fear of divorce and breach the arbitration system is the most effective strategy to reach a compromise.

\section{Arbitration System}

As it was mentioned before the Quranic strategy for resolving sexual problems between the spouses is in secrecy and inside the family so that the secrets of the family are not revealed to others. It is obvious that based on the recommendation of Quran the spouses should act in a special and unique way, and be flexible (they are a vestment for you, and you are a vestment for them - al-Baqarah, 187). Thus, before thinking of the logical aspect and justice, they should act according to emotion and feeling and be flexible, so that the family gets the safe shore of love and mercy. Yet it might happen that the marital problems between the spouses cannot be resolved and there's fear of breach. In such cases, the holy Quran suggests arbitration to avoid divorce. It seems that in all cases arbitration is calling to good, and that's why the verse is addressed to all Muslims (Hosseini Shirazi, 2002) and everyone should cooperate in doing it: And if you fear a breach between the two, bring forth an arbiter from his people and from her people an arbiter, if they desire to set things right; God will compose their differences; surely God is All-knowing, All-aware.

According to this verse the only condition mentioned for the arbiters is that they be from among relatives of the spouses. Some jurists think of this condition as being essential (Tabatabaee, 1984, Mousavi Khomeini, 1988, Vahli, 1989, Shahid Sani, 1989). Apparently the emphasis of Quran on this matter is because relatives are reliable and are more familiar with the characteristics of the spouses; as a result, they can be of more help in resolving the matter. Furthermore, relatives act in a way that the problem remains confidential to the family. About the nature of arbitration it is necessary to mention the following: arbitration consists of legal proceedings, based on the request of the spouses, for recognition and enforcement of their rights and duties (Ginnings, 1989). Arbitration has jurisprudential legitimacy and is considered as a kind of judgment in jurisprudence (Khoei, 1989). The person is entitled as arbitrator (Mousavi Ardebili, 1987) whose order is operative and mandatory for the spouses (Mohaghegh Helli, 1987). The legitimacy of arbitration is undeniable according to the Holy Book and the Traditions of the prophet.

The holy Quran has confirmed legitimacy of arbitration in many verses. In addition to the previously mentioned ones, verse 65 of surah an-Nisa confirms this: But no, by thy Lord! They will not believe till they make thee the judge regarding the disagreement between them, then they shall find in themselves no impediment touching thy verdict, but shall surrender in full submission.

The traditions of al-Halabi (Ameli, 1971), Abu Khadijeh, Musa Ibn Aqil (Ameli, 95), and the Hadith said by Ibn Qudamah (Najafi, Bita, vol. 40, p 16) have all confirmed legitimacy of arbitration. 
It's a controversial issue among the jurists whether the order of arbiter is obligatory or satisfaction of the parties is needed. As was said most of the jurists have referred to the verse about breach for matters of arbitration. According to the appearance of the verse and accepting that the addressees are judges, it's a strong possibility that no condition is put (Najafi, vol. 40, p 22).

In Iranian law, arbitration has had a long history. Before the formation of state courts of justice, and organized judicial system in Iran, the disputes between people were resolved by going to arbiters. After legislation and formation of state courts, the temporary code of civil procedures enacted in 1899 had an article allocated to arbitration. Then in 1927 with a separate arbitration code, the legislator went too far and made arbitration obligatory. In 1934 another code in arbitration was enacted and obligatory arbitration principle was stopped totally. Finally civil procedure code was enacted in 1939, the eighth chapter of which was allocated to arbitration, and abolished all previous codes. From the code of 1939 afterwards taking the case to arbiter is based on choice and mutual consent, and only in specific instances arbitration is obligatory. After enactment of the code of procedure for public and revolutionary court (in civic affairs) in 2000 the civil procedure code of 1939 was abolished.

The mentioned code has been approved in Islamic Consultative Assembly in 09.04.2000, and then in 16.04.2000 was confirmed by The Guardian Council (the collection of laws, 2001). The seventh chapter of this code is allocated to arbitration. The legislator has used the former code as a model and tried to adapt it to the principles of constitution and other regulations.

Taking the case to arbitration at the time of giving the verdict of divorce has entered the Regulations Concerning Divorce Reform Act in 20.10.1992. It states that the spouses who want to take a divorce should go to family court to initiate proceedings. The article one of the executive regulation of the first note of Regulations Concerning Divorce Reform Act Single-clause bill, approved in February 20, 1993, requires that divorce requests from spouses (or one of them) be submitted to family courts. If the case is not resolved at the court, proceedings are referred to arbitration with issuance of writ.

According to article two of the executive regulation, the spouses are required to introduce one of their relatives as arbiter within 20 days. According to the regulation it is obligatory in divorce cases to refer the case to arbitration, and the divorce verdict is given only if the case is referred to arbitration. Decisions of the Supreme Court, including decision no. 427, dated July 28, 1993, branch 22 of the Supreme Court, also state that giving the divorce verdict before referring the case to arbiter is wrong (Bazgir, 1998). Therefore, all divorce cases in family courts must be referred to arbitration by the judge; while in other cases like submission, maintenance, and abandonment of family, there're no obligatory regulations to refer the case to arbitration. On the other hand, in some cases where divorce is obligatory referring it to arbitration has no sense. Moreover, using the word "fear" in verses 35,128 , and 34 of surah an-Nisa, based on which referring the case to arbitration is emphasized, indicates that this order is for the time when there's fear of separation and breach; in other words, if there's certainty about breach, no arbitration will be needed.

\section{Conclusions}

According to different psychological and physical conditions of the spouses, problems in marital relationships might occur at any time in the mutual life. Disobedience and lack of submission from the wife mentioned in verse 34 of surah an-Nisa is called wife's nushuz. Reluctance of the husband mentioned in verse 128 of surah an-Nisa is called husband's nushuz. If this problem is from both sides, it is called spouses' nushuz and breach, as mentioned in verse 35 of surah an-Nisa. In fact nushuz is a damage which the wife or the husband, who refuses to fulfill marital duties, inflicts upon the foundation of family. In order to avert the damage the Holy Quran has considered special strategies according to the rule that there's no detriment and detrimental act in Islam. In an instance of wife's nushuz, according to the verse "Men are the managers of the affairs of women..." husband is responsible to make things right. Because the family foundation is based on love and mercy, the problem is at the first stage resolved through admonishment and banishment. If these two strategies prove ineffective, and there is possibility of the problem being resolved through beating, the husband can practice it to avert the damage. Using this Quranic strategy prevents the family from going to justice courts and keeps the secrets to the family. Thus, if beating weakens the family foundation, it is not allowed. Although scholars have justified the word "zarb" in different ways, according to the clarity of the verse it means beating as a warning in a way that does not cause bruises on her body or lead to compensation. In fact, beating is a kind of showing dissatisfaction, and does not mean conventional beating. It is obvious that the same strategies cannot be used for husband's nushuz; because there are differences from all aspects between the spouses. Wife is not the agent but a stimulus for the agency. Therefore, if nushuz is from the husband, using strategies of banishment and beating can result in isolation and 
retreat. Considering all of the aforementioned verses together we can say that, if the husband was not able to resolve wife's nushuz through admonishment, banishment, and beating, and also if the wife was not able to resolve husband's nushuz through compromise, it would be time for referring the case to arbitration and selecting arbiters form among relatives. Using the arbitration system is completely necessary in all cases, including problems of marital relationships. Therefore, laying down regulations in all aspects of family and disagreements in every stage, and in cases that the spouses cannot use the strategies given in verses 34 an 128 of surah an-Nisa, should be done considering arbitration system.

\section{References}

Abo, Soleyman, \& Abdel, Hamid, Ahmed. (2002). Beating women and a way to resolve marital problems. Dameshgh: Dar al-fikr.

Arberry, Arthur, John. (1955). The Koran Interpreted.

Bazgir, Yadollah. (1998). The Supreme Court decisions in legal affairs (1st ed.). Ghoghnus Publications.

Bojnurdi, Seyyed, Mohammad. (1998). Islam does not accept violence against women. Women's rights monthly, Tehran, 1(3), 7-25.

Bohrani, Yousef. Fresh gardens in the provisions of the pure strain. Newsletter of Islamic affiliated group of teachers. Qom.

Balaghi, Najafi, \& Muhammad, Jawad. Aala'-ir-Rahman Fi Tafsir-al-Quran. Qom: Bonyad-e-be'sat publications.

Jafari, Mohammad, Taghi. (1997). The interpretation of Nahj al-Balagha(7th ed.). Tehran: Office of Islamic culture publications.

Javadi, Amoli, Abdollah. (2005). Right and duty. Qom: Asadi publications.

Hosseini, Jorjani, \& Seyyed, Amir, abolfotuh. (1984). Revelations of Provisions (1st ed.). Tehran: Navid publications.

Hosseini, Shirazi, \& Seyyed, Mohammad. (2002). Explanation of Quran (2nd ed.). Beirut: Dar-al-Olum.

Horr, Ameli, \& Mohammad, Ibn, Hasan. (1971). Wasa'el al-Shiah (4th ed.). Beirut: Dar Ihya At-Turats Al-'Arabi.

Ibn, Manzur, \& Muhammad, Ibn, Mokarram. (1993). Lisan al-Arab (3rd ed.). Beirut: Dar Sader.

Ragheb, Isfahani, \& Hossein, Ibn, Mohammad. (1991). Al-Mofradat (1st ed.). Beirut: Dar-al-elm.

Shahid, Sani. (1989). Sharh allam'a-d-Dimashqiya (1st ed.). Qom: Davari publications.

Safaei, Seyyed, Hossein. (2008). A summary of family law (10th, ed.). Tehran: Mizan.

Sadough, Mohammad, Ibn, Babouyeh. (1981). Man La Yahzarah al-Faqih (1st ed.). Beirut: Dar-al-Ta'arif.

Tabatabaee, Seyyed, Ali. (1998). Rizad al Masa'il (1st ed.). Qom: Institute of Islamic Publicatiions.

Tabresi, Fazl, Ibn, Hasan. (1993). Majma' Al-Bayan in Tafseer Al-Qur'an (3rd ed.). Tehran: Naser Khosro Publications.

Tabari, Mohammad, Ibn, Hariri. (2001). Tafsir al-Tabari, research by Abdol Mohsen al-Torki. Cairo: Hejr Publications.

Qaeni, Mohsen. (1994). Beating as a sign of man's leadership. Tahran: Women's magazine.

Gharshi, Seyyed, Ali, Akbar. (1991). Vocabulary of the Quran (6th ed.). Tehran: Dar al-kotob al-islamiyeh.

Qartabi, Mohammad, Ibn, Ahmad. (1995). Whole jurisprudential provisions. Cairo: dar al-Hadith.

Kashani, Molla, Fath, Allah. (1957). Manhaj-us-Sadiqeen. Tehran: Mohammad Hasan Elmi Bookstore.

Kazemi, Javad, Ibn, Saeed. (1976). Masalek al-Afham ela Ayat al-Ahkam (2nd ed.). Tehran: Mortazavi Bookstore.

Ginnings, Arthur, T. (1989). Commercial Arbitration and its principles in the English Law. Legal magazine. Tehran : office of international legal services publication.

Majlesi, Mohammad, Bagher. (1994). Bihar al-Anwar (3rd ed.). Tehran: dar al-kotob al-islamiyeh.

Mohaghegh, Helli. (1989). Sharaye' al-Islam. Davari publications.

Motahari, Morteza. (2007). The Women's Rights in Islam (49th ed.). Tehran: Sadra.

Mostafavi, Hasan. (1982). Investigation in Quran's words (1st ed.). Tehran: al-Ketab let-Tarjomeh val-Nashr center. 
Ma'refat, Mohammad, Hadi. (2002). Suspicions around Quran. Qom: a-Shahid institute.

Moein, Mohammad. (2003). Farhang-e-Moein (1st ed.). Tehran: Sigol.

The collection of laws (1st ed.). (2001). Islamic Republic of Iran Official Newspaper Stock Company.

Mousavi, Ardabili, \& Seyyed, Abdol, Karim. (1987). Jurisprudence (1st ed.). Qom: Maktabat Amir al-Mo'menin publications.

Mousavi, Khomeini, \& Seyyed, Ruh, Allah. (1988). Tahrir al-Vasileh (2nd ed.). Najaf: Aadab.

Mousavi, Khoei, \& Seyyed, Abolqasem. (1981). The principles of Takmilah al-Manhaj. Beirut: Dar a-Zahra.

Najafi, Sheikh, Mohammad, Hasan. Jawaher al-Kalam. Beirut. 